\title{
3D geophysical inversion modeling of gravity data to test the 3D geologic model of the Bradys geothermal area, Nevada, USA
}

\author{
Jeffrey B. Witter ${ }^{1,2^{*}}$, Drew L. Siler ${ }^{3}$, James E. Faulds ${ }^{4}$ and Nicholas H. Hinz ${ }^{4}$
}

\author{
*Correspondence: \\ jeff@innovategeothermal.com \\ ${ }^{1}$ Mira Geoscience Ltd., 409 \\ Granville Street, Suite 512B, \\ Vancouver, BC V6C 1T2, \\ Canada \\ Full list of author information \\ is available at the end of the \\ article
}

\begin{abstract}
Three-dimensional geophysical inversion modeling of gravity data has been performed to test the validity of a 3D geologic model constructed for the Bradys geothermal area. Geophysical modeling was implemented in three different ways: (1) fully unconstrained (i.e., no geologic data included); (2) constrained by the 3D geologic model using homogeneous rock unit densities, and (3) constrained by the 3D geologic model using heterogeneous rock unit densities. We show that the existing 3D geologic model of the Bradys area is broadly consistent with the gravity data. At a more detailed level, however, our analysis suggests that some adjustments to the Bradys 3D geologic model would improve agreement between the observed gravity and the calculated gravity response. The results of the geophysical inversion modeling are important as they serve as a guide to show where and how the boundaries of the 3D geologic model may need to be adjusted to address density excesses and deficiencies. A 3D geologic model that has been independently tested prior to drilling (using a method such as that described in this paper) will be more robust and have less uncertainty than those which have not been tested. Such an approach will facilitate a reduction in drilling risk, lead to more successful drilling programs, and provide valuable geologic input to improve the accuracy of reservoir models.
\end{abstract}

Keywords: Geothermal exploration, Conceptual models, 3D geophysical inversion modeling, Gravity data, Bradys geothermal system, GOCAD, VPmg

\section{Introduction}

\section{Background}

Conceptual models of geothermal systems are commonly constructed using a variety of geoscience datasets and models (Cumming 2009a). These might include: resistivity models from magnetotelluric surveys, structural information from geologic mapping and/ or seismic surveys, various drilling logs, and reservoir temperature estimates from geothermometry analysis. Unfortunately, current geothermal exploration best practice does not include steps to independently test the validity of a conceptual model prior to drilling (IFC 2014). Drilling is an expensive method for testing conceptual models. If such an independent and economical test of validity were available, we could increase our pre-drilling understanding of the subsurface and more confidently identify new drilling 
targets. We could also increase the success rate of drilling programs and ultimately, reduce the cost of geothermal development.

Thanks to advances in the mineral exploration sector, potential field techniques are available to independently test geological conceptual models in three dimensions without drilling (Oldenburg and Pratt 2007; Fullagar and Pears 2007; Fullagar et al. 2008). Such techniques utilize gravity and/or magnetic data, rock property data (i.e., density, magnetic susceptibility), and a 3D geologic model. The approach involves forward and inverse modeling of the geophysical data constrained by both the geologic model and rock property data (e.g., Blaikie et al. 2014; Perrouty et al. 2014; Miller and WilliamsJones 2016). An assessment of the output can ascertain, quantitatively, whether or not an existing geological conceptual model is consistent with the geophysical data measured at the surface. If not, the geological conceptual model and/or geophysical interpretations need to be altered to achieve a better fit. An advantage of the method described here is that it identifies specific areas where the conceptual model is not consistent with the geophysical data and provides information on how the conceptual model could be updated to achieve consistency.

In this study, we use gravity data to test an existing 3D geologic model of the Bradys geothermal field in west-central Nevada, USA. To achieve this, we performed 3D geophysical inversion modeling of the gravity data in three ways: (1) fully unconstrained (i.e., no geologic data included); (2) constrained by the 3D geologic model using homogeneous rock unit densities, and (3) constrained by the 3D geologic model using heterogeneous rock unit densities. We tested the existing 3D geologic model based upon our present (limited) understanding of rock densities in the Bradys geothermal study area. Despite this limitation, we show that the existing 3D geologic model of the Bradys area is broadly consistent with the gravity data. Further work is needed to better quantify rock densities to facilitate a more rigorous analysis and update of the existing 3D geologic model and geophysical interpretations.

\section{Bradys geothermal field}

The Bradys geothermal field is located approximately $80 \mathrm{~km}$ east-northeast of Reno, Nevada (USA) within the Basin and Range physiographic province (Benoit et al. 1982; Faulds and Garside 2003; Faulds et al. 2003, 2010a, 2012; Fig. 1), a region of tectonic extension well-recognized for elevated heat flow (Lachenbruch and Sass 1978). In the mid-nineteenth century, the Bradys area contained many boiling hot springs and was known as Tenderfoot Station to the passing pioneers. A resort and spa occupied the site for many years in the mid-twentieth century. Drilling programs in the 1960s and 1970s led to the world's first geothermal food processing plant built on the site in 1978 (Benoit et al. 1982).

A geothermal power plant has been in operation at the site since 1992. The current plant is a combined flash and binary power plant with 26 MWe installed capacity. The geothermal production wells that feed the power plant tap a $180-193{ }^{\circ} \mathrm{C}$ reservoir that lies at a depth of 1-2 km below the surface (based upon publically available data, Nevada Division of Minerals, and Benoit et al. 1982). 


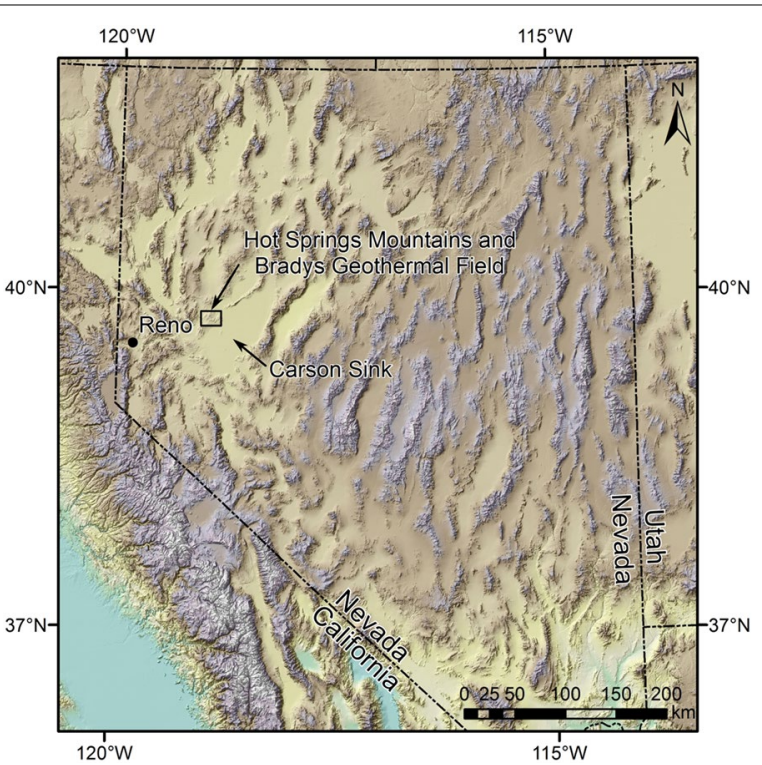

Fig. 1 Location map for the Bradys geothermal field in western Nevada (USA). Other geographic features referred to in the text are also shown

\section{Stratigraphy and structure of the Bradys geothermal field}

The Bradys geothermal field is located in the northern portion of the Hot Springs Mountains. The geology of these mountains is characterized by thick ( 1 to $2+\mathrm{km}$ ) sections of volcanic and sedimentary rocks of Miocene age ( 15 to $7.5 \mathrm{Ma}$; Faulds and Garside 2003; Faulds et al. 2003). These rocks are underlain locally by Oligocene ash flow tuffs. The Tertiary section rests nonconformably on Mesozoic metamorphic/plutonic basement rocks (Stewart and Perkins 1999; Faulds et al. 2012). This stratigraphy is dissected by numerous en echelon, overlapping north-northeast-striking normal faults, which demarcate multiple north-northeast trending fault blocks (Faulds et al. 2010a). The main episode of extension occurred $\sim 13$ to $9 \mathrm{Ma}$ (Faulds et al. 2010a), but several fault scarps cutting Quaternary deposits provide evidence for ongoing extension in the area (Trevor and Wesnousky 2001; Wesnousky et al. 2005; Faulds et al. 2012). The north-northeaststriking, west-northwest-dipping Bradys fault zone is understood to be the controlling structure for the Bradys geothermal field (Fig. 2; Faulds et al. 2012, 2013). A zone of extensive sinter, warm ground, fumaroles, and mud pots mark the surface expression of the Bradys fault zone over a distance of $\sim 4 \mathrm{~km}$ (Coolbaugh et al. 2004; Faulds et al. 2012). A $\sim 1 \mathrm{~km}$-wide left step-over in the Bradys fault zone has been identified from surface mapping. The down-plunge projection of this step-over, which lies within a broader accommodation zone of overlapping west- and east-dipping normal faults, is presumed to produce a region of fault intersections and high fracture density that facilitates geothermal fluid upflow (Faulds et al. 2006, 2010a, b, 2013).

\section{D geologic modeling of the Bradys geothermal field}

3D geologic modeling at Bradys was performed using established methods (Moeck et al. 2009; Jolie et al. 2012; Siler et al. 2012; Siler and Faulds 2013; Siler et al. 2016a). The initial 3D model of Bradys by Jolie et al. (2015) was followed by more detailed modeling by 


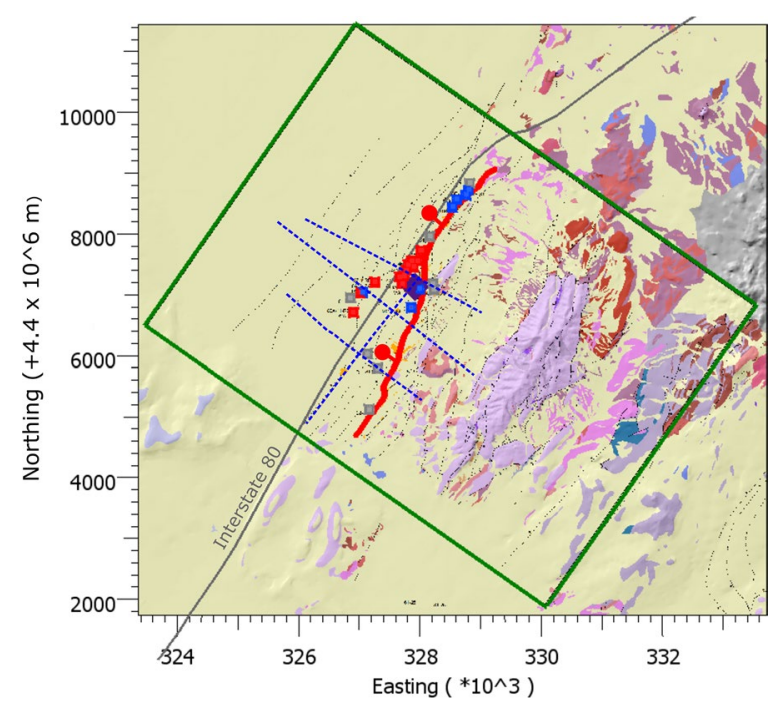

Fig. 2 Simplified geologic map of the region surrounding the Bradys fault zone (after Faulds et al. 2010a, b, 2012). Purple, red and pink rock units are Miocene volcanic and sedimentary rocks; the buff colored unit is Quaternary alluvium. The abundant normal faults are shown as thin, black dotted lines. The main trend of the NNE-trending, WNW-dipping Bradys fault zone is shown by the red solid line. Balls on downthrown sides of faults. The purple diamond shows the location of the Bradys geothermal power plant. Squares show the locations of geothermal production wells (red), injection wells (blue), and other wells (grey). The green rectangle shows the 3D model boundary. Blue dashed lines show the locations of four seismic sections used to help construct the 3D geologic model. Coordinates are UTM NAD83 zone 11

Siler et al. (2016a). The Bradys 3D geologic model was constructed based on 1:24,000 scale geologic mapping (Faulds et al. 2012), stratigraphy interpreted from the mapping and lithologic analyses of cuttings and core from 21 wells, interpretation of four seismic reflection profiles, and construction of four detailed geologic cross-sections. The Bradys geologic framework is characterized by a highly faulted Oligocene to Quaternary 1500-m-thick stratigraphic section of interfingering and discontinuous mafic to intermediate composition lava flows, ash flow tuffs, and various sedimentary units including siltstone, diatomite, and limestone (Faulds et al. 2012). The fault relationships in the area are complex. The Tertiary units within the Bradys geothermal field generally dip gently to moderately southeast on the western limb of an extensional syncline. Normal displacement on the northeast-striking, northwest-dipping Bradys fault zone accommodated the southeast tilting of fault blocks (Faulds et al. 2010a, b). The Bradys fault zone is manifest as a set of the north- to northeast-striking west- to west-northwest-dipping, anastomosing normal fault strands. In addition to these primary fault strands, the $\sim 1$-km-wide left step-over in the Bradys fault zone consists of several secondary faults and fault segments oblique to the primary strike of the fault zone (Faulds et al. 2010a, 2012; Siler and Faulds 2013; Siler et al. 2016).

\section{Previous studies}

Other researchers have conducted integrated geological/geophysical modeling studies in the Great Basin in an attempt to better understand the complex geology and structure of the region. For example, Watt et al. (2007) modeled gravity and magnetic data to generate a 3D geologic model of the northern Nevada rift, which contains the Beowawe 
geothermal system. Egger et al. (2010) investigated the structural controls on the Surprise Valley extensional basin in northeastern California by integrating geologic mapping with 2D potential field and seismic velocity modeling. Cox et al. (2013) studied the crustal structure and tectonic evolution of the High Lava Plains region of eastern Oregon through an integration of seismic, gravity, and geologic information. Khatiwada and Keller (2015) focused on the Harney Basin of the High Lava Plains region and employed geologic, gravity, magnetic, digital elevation, and other geospatial data to execute an integrated geoscience study. Queen et al. (2016) conducted a high-resolution reflection seismic survey as well as a vertical seismic profile in a well at the Bradys geothermal area. They generated a 3D seismic velocity model for the area which proved useful for mapping faults and lithologic boundaries where integrated with other geological and geophysical data.

\section{Methods}

Three different geophysical modeling approaches were utilized in this study:

1. 3D unconstrained, heterogeneous density modeling

2. 3D geologically constrained density modeling with homogeneous rock units

3. 3D geologically constrained density modeling with heterogeneous rock units.

All three types of modeling involve iterative inversion of gravity data to generate a 3D density model. The software used to perform the modeling includes GOCAD Mining Suite (for 3D visualization and model management) linked to VPmg software (for the geophysical modeling). Geophysical modeling of any type suffers from the problem of non-uniqueness. In other words, the geophysical model result may be acceptable mathematically, but may be incorrect geologically. We chose to pursue a variety of geophysical modeling approaches in order to explore the density model space and help facilitate an improved geological interpretation. The local geophysical model volume has the dimensions $8 \mathrm{~km} \times 6 \mathrm{~km} \times 2.5 \mathrm{~km}$ and is oriented northwest-southeast, centered approximately over the Bradys geothermal power plant. A cell size of $100 \mathrm{~m}$ was chosen to be compatible with the gravity data available for modeling. The local geophysical model volume was populated with rock types from the 3D geologic model (Fig. 3). The local geophysical model volume was also incised into a regional geophysical model volume that has approximate dimensions of $48 \mathrm{~km} \times 46 \mathrm{~km} \times 25 \mathrm{~km}$. The regional geophysical model was populated with density values by performing 3D heterogeneous inversion modeling (Fullagar and Pears 2007) on the regional gravity data. This regional geophysical volume accounts for long wavelength gravity signal in the 3D geophysical modeling.

\section{Gravity data}

The gravity data used in this study are public domain from the Nevada Bureau of Mines and Geology (NBMG) and National Geothermal Data System (NGDS 2015). These data were acquired by others in two stages: (1) initially as part of a detailed gravity survey of the northern Hot Springs Mountains (Faulds et al. 2003) and (2) later supplemented by a more regional gravity analysis of the Carson Sink (Faulds et al. 2014). After collection of the gravity data, the following data processing steps were applied. The gravity 


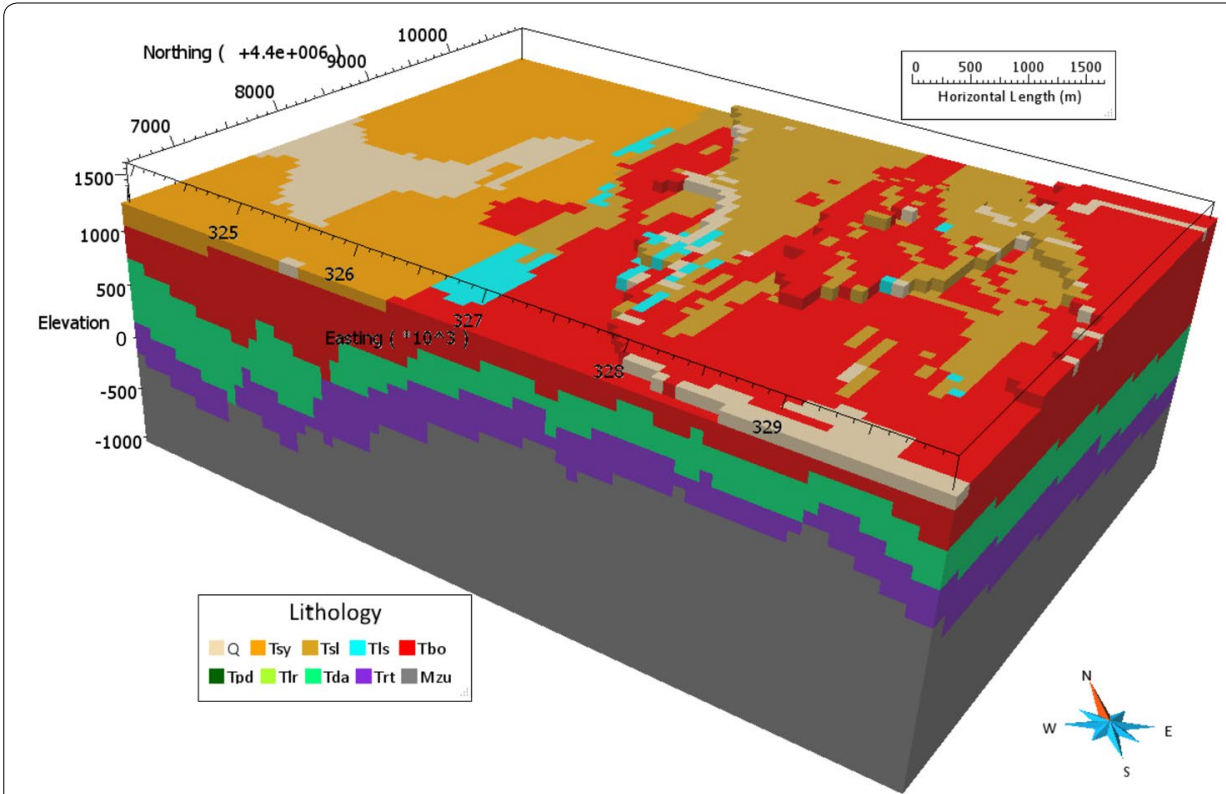

Fig. 3 Perspective towards the north of the 3D geological block model for the Bradys geothermal area used for 3D geophysical modeling. The geologic model shown corresponds to the local 3D geophysical model volume. The local model volume has the dimensions $8 \mathrm{~km} \times 6 \mathrm{~km} \times 2.5 \mathrm{~km}$, is oriented northwest-southeast, and is centered approximately over the Bradys geothermal power plant. The 3D geologic model shown consists of cells $100 \mathrm{~m} \times 100 \mathrm{~m} \times 100 \mathrm{~m}$. Colors represent different rock units shown in the legend. Rock unit codes are defined in Table 1. Coordinates are UTM NAD83 zone 11. Elevation is in meters

data were referenced to a base station. This base was tied to absolute gravity station Fallon DOD reference number 2351-1 with IGSN 71 value of $979,730.77 \times 10^{-5} \mathrm{~m} / \mathrm{s}^{2}$. Gravity data processing was performed by others using Geosoft Oasis Montaj Gravity and Terrain Correction software version 7.1. Corrections applied to the raw gravity data included: instrument height, instrument scale factor, instrument drift, earth tides, latitude (1984 ellipsoid), and elevation to produce the Free Air (Heiskanen and Moritz 1967), Simple Bouguer, and Complete Bouguer Anomalies. The Bullard B correction was applied to the Simple and Complete Bouguer Anomalies. The Complete Bouguer Anomaly includes corrections for the effect of surrounding topography. Within a radius of $10 \mathrm{~m}$ of each station, slope measurements were made with an inclinometer for use in the terrain correction. From $10 \mathrm{~m}$ to a radius of $167 \mathrm{~km}$ the terrain correction utilized National Elevation Dataset 1 Arc Second digital terrain data. The Complete Bouguer Anomaly values for each gravity station used in this study were calculated using a density of $2.5 \mathrm{~g} / \mathrm{cm}^{3}$. The focus of the 3D geophysical modeling effort is an $8 \mathrm{~km} \times 6 \mathrm{~km}$ rectangle oriented northwest-southeast and centered approximately over the Bradys geothermal power plant. Gravity station spacing within this local geophysical model area is highly variable and ranges from $200 \mathrm{~m}$ to $2 \mathrm{~km}$ (Fig. 4). These gravity datapoints were gridded within the local study area using an inverse distance gridding algorithm and a cell size of $100 \mathrm{~m}$. Regional gravity data outside of the local study area (extending out to a distance of $\sim 20 \mathrm{~km}$ ) were also gridded using an inverse distance algorithm, but we used a cell size of $500 \mathrm{~m}$ due to the a larger average spacing between gravity stations (from $500 \mathrm{~m}$ to $5 \mathrm{~km}$ ) at the regional level. Both of these gridded gravity datasets 


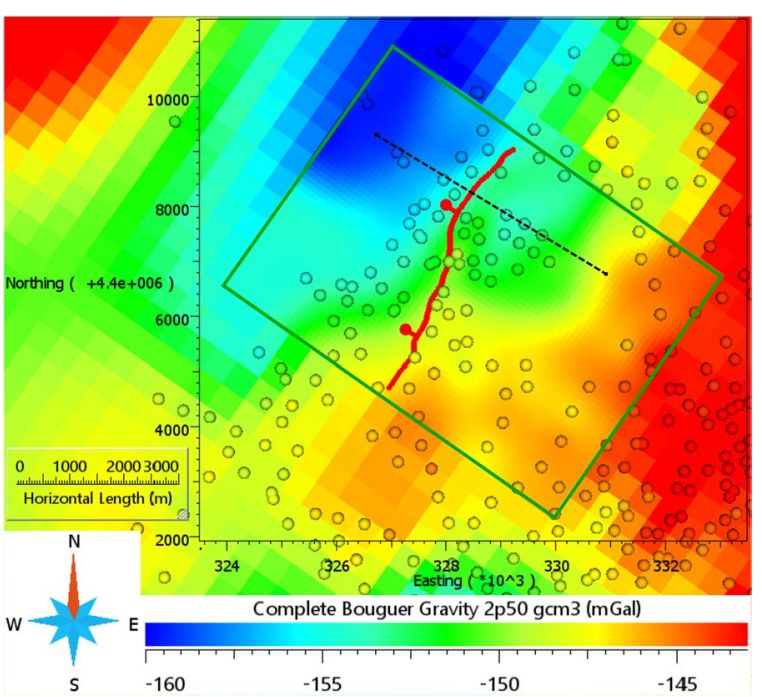

Fig. 4 Gravity map of the Bradys geothermal area showing: (1) locations of the gravity stations (spheres), (2) gridded gravity data within the local study area with $100 \mathrm{~m}$ cells, and (3) gridded regional gravity data surrounding the local study area consisting of $500 \mathrm{~m}$ cells. All gravity data are Complete Bouguer Gravity referenced to a terrain density of $2.5 \mathrm{~g} / \mathrm{cm}^{3}$. The green rectangle shows the $\sim 8 \mathrm{~km} \times \sim 6 \mathrm{~km}$ local study area in which the 3D geophysical inversion modeling was performed. The main trend of the Bradys fault zone is shown by the red solid line. The black dashed line is the location of the cross-section shown in Fig. 6. Coordinates are UTM NAD83 zone 11

(local and regional) were used for the 3D geophysical inversion modeling. The purpose of the regional $(500 \mathrm{~m})$ gravity grid is to provide a regional gravity context for the more detailed $(100 \mathrm{~m})$ local gravity grid within the study area and minimize edge effects in the geophysical model output.

Since the gravity data used in this study are public domain and were collected in various studies spanning more than 10 years, the uncertainty in the gravity measurements is unknown. We estimated the uncertainty as $10 \%$ of the standard deviation of the amplitude of the gravity data. For the study area, this value is $0.5 \mathrm{mGal}$. During the geophysical modeling effort, we attempted to reduce the level of misfit between observed and calculated data to match this data uncertainty value.

\section{D unconstrained, heterogeneous density modeling}

The first geophysical modeling approach applied to the Bradys gravity data is a fully unconstrained inversion to create a 3D model with heterogeneous density distribution. No geological information is included in the geophysical modeling process. Dense bodies are distributed at depth using a standard depth weighting scheme (Li and Oldenburg 1998). The purpose of performing this unconstrained modeling is threefold: (1) obtain a general understanding of the range of rock density values expected in the subsurface; (2) obtain a general understanding of the potential spatial distribution of density in the subsurface, and (3) generate one possible density distribution that is unbiased by geological information. The result of this unconstrained model can be interpreted on its own. However, it is also useful to serve as a comparison with the other geophysical model results that include geological constraints. 


\section{D geologically constrained density modeling with homogeneous rock units}

Unconstrained geophysical modeling described above can provide a general guide at best and be misleading at worst due to the problem of non-uniqueness. In order to increase the geological relevance of geophysical models, geological information should be incorporated into the geophysical modeling process to guide it toward a result consistent with the actual observed geology (Saltus and Blakely 2011).

One approach that we employed for this study is to use the 3D geologic model (Fig. 3) as a constraint on the geophysical modeling. The 3D geologic model defines discrete volumes for the different rock units. Each rock unit is also assigned a different density based upon its expected average density (Table 1). Geophysical forward modeling was performed to calculate the gravity response of the 3D geologic model with the assumed rock unit densities. By comparing the observed gravity response (obtained from fieldbased gravity measurements) with the gravity response calculated from the 3D geologic model, we can ascertain how well the existing geologic model fits with the observed gravity data.

Usually, the misfit is unacceptably large between observed and calculated gravity values after initial forward modeling. This can occur for three reasons: (1) the assumed rock density values may be inaccurate; (2) the rock units may not be homogeneous in density, and (3) there may still be uncertainty in the boundaries of the rock units in the 3D

Table 1 Densities of rock units

\begin{tabular}{|c|c|c|c|c|c|}
\hline Rock unit & Rock type & $\begin{array}{l}\text { Starting density } \\
\left(\mathrm{g} / \mathrm{cm}^{3}\right)\end{array}$ & $\begin{array}{l}\text { Homogeneous } \\
\text { unit density } \\
\text { inversion output } \\
\left(\mathrm{g} / \mathrm{cm}^{3}\right)\end{array}$ & $\begin{array}{l}\text { Heterogeneous } \\
\text { unit density } \\
\text { inversion output } \\
\left(\mathrm{g} / \mathrm{cm}^{3}\right)\end{array}$ & $\begin{array}{l}\text { Abundance of the } \\
\text { rock unit }^{\mathrm{a}}(\%)\end{array}$ \\
\hline Q & $\begin{array}{l}\text { Quaternary sedi- } \\
\text { ments }\end{array}$ & 1.9 & 2.33 & 1.9 (fixed) & 0.5 \\
\hline Tsy & $\begin{array}{l}\text { Miocene sedi- } \\
\text { ments }\end{array}$ & 2.1 & 2.09 & $2.03-2.15$ & 3.2 \\
\hline Tsl & $\begin{array}{l}\text { Miocene lacus- } \\
\text { trine sediments }\end{array}$ & 1.7 & 2.2 & $2.14-2.20$ & 3.0 \\
\hline Tls & $\begin{array}{l}\text { Miocene lime- } \\
\text { stone }\end{array}$ & 2.35 & 2.46 & $2.40-2.52$ & 0.6 \\
\hline Tbo & Miocene basalt & 2.7 & 2.55 & $2.49-2.61$ & 20.3 \\
\hline Tpd & $\begin{array}{l}\text { Miocene dacite } \\
\text { and rhyodac- } \\
\text { ite flows and } \\
\text { domes }\end{array}$ & 2.4 & 2.04 & $1.98-2.10$ & 0.3 \\
\hline Tlr & $\begin{array}{l}\text { Miocene rhyolite } \\
\text { lavas and tuffs }\end{array}$ & 2.15 & 2.3 & $2.24-2.36$ & 0.3 \\
\hline Tda & $\begin{array}{r}\text { Miocene andesite } \\
\text { and dacite lavas }\end{array}$ & 2.5 & 2.1 & $2.04-2.16$ & 15.8 \\
\hline Trt & $\begin{array}{l}\text { Oligocene ash } \\
\text { flow tuffs }\end{array}$ & 2.3 & 2.74 & $2.68-2.80$ & 11.1 \\
\hline Mzu & $\begin{array}{l}\text { Mesozoic undi- } \\
\text { vided basement } \\
\text { (meta-sedimen- } \\
\text { tary and granitic } \\
\text { rocks) }\end{array}$ & 2.8 & 2.6 & $2.54-2.66$ & 44.9 \\
\hline
\end{tabular}

Density values for rock types at Bradys geothermal area: assumed starting densities, density results from the homogeneous rock unit geophysical inversion modeling, and density results from the heterogeneous rock unit geophysical inversion modeling (assumed starting densities were guided by values from analogous rock units in northwestern Nevada; Drakos 2007)

a As a percentage of the total model volume 
geologic model. Ideally, we want to reduce the amount of misfit between the observed and calculated gravity to a low level consistent with the uncertainty in the observed gravity data. One way to reduce this misfit would be to utilize more representative density values in the geophysical modeling. A sufficiently large database of density values that covers the Bradys area for all the rock units in question was not available for this study. Therefore, we employed geophysical inversion modeling to find density values for each of the 10 rock units that, collectively, minimize the misfit. These modeled densities are homogeneous throughout each individual rock unit.

\section{D geologically constrained density modeling with heterogeneous rock units}

Some rock units that have been demarcated on geologic maps and/or within geologic models are not homogeneous in density. For example, volcanic sections that contain both dense lavas and low-density volcanic tuffs may occupy the same rock unit. Therefore, to make our geophysical modeling effort geologically more realistic, it is appropriate to allow for variable (heterogeneous) density within individual rock units. As a final step in the geophysical modeling presented here, we performed a second stage of inversion modeling to further reduce the misfit. This time we allowed the density values to vary in each rock unit within geologically reasonable bounds. The density of the Quaternary sediments $(\mathrm{Q})$ was fixed at $1.9 \mathrm{~g} / \mathrm{cm}^{3}$ because the thickness of this unit is less than $100 \mathrm{~m}$-such a thin geologic layer is difficult to resolve considering the wide spacing of the gravity stations.

\section{Results}

\section{D unconstrained, heterogeneous density modeling}

The unconstrained inversion modeling ran for 8 iterations and resulted in a 3D model with densities in the range from 2.42 to $2.58 \mathrm{~g} / \mathrm{cm}^{3}$. Some general features of the unconstrained density model are in agreement with the known geology. For example, model densities to the west of the Bradys fault zone are low, reflecting greater thicknesses of lower density late Miocene to Quaternary sediments overlying downthrown fault blocks of higher density material. Similarly, model densities are mostly higher to the east of the Bradys fault zone, where thick sections of relatively dense middle-to-late Miocene basalt crop in parts of the area (Fig. 5a). The unconstrained density model, however, does not resolve the lateral variations in density that arise due to the tilted stratigraphy and fault blocks at Bradys. Notably, density isosurfaces within the unconstrained model are mostly near-vertical (Fig. 5b). Furthermore, from the perspective of geologic structure, the unconstrained model does not provide a reliable representation of the orientation and throw of faults (Fig. 6). However, the observed gravity data match well with the gravity response calculated from the unconstrained density model (Fig. 7). In addition, the overall RMS misfit of the model $(0.46 \mathrm{mGal})$ is similar to the gravity data uncertainty (0.5 mGal). Thus, we have constructed for the Bradys area a density model that is mathematically correct but geologically questionable.

\section{D geologically constrained density modeling with homogeneous rock units}

The 3D geologic model populated with the assumed, homogeneous rock unit density values (Table 1) is shown in Fig. 8. Geophysical forward modeling of this geologic model 


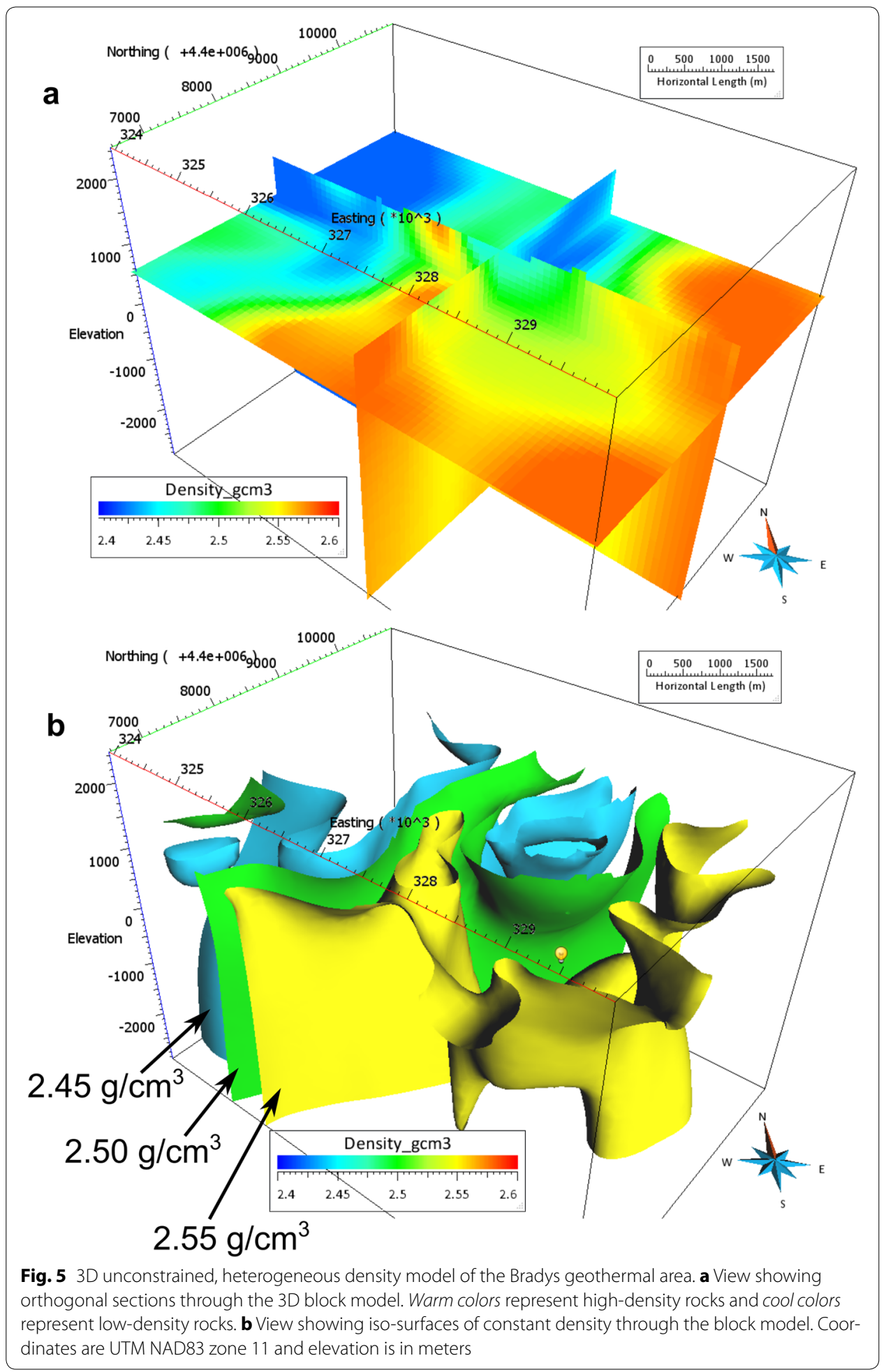

produced the calculated gravity response and misfit shown in Fig. 9. The calculated data match the main features of the observed gravity data (low in the west, high in the east). However, the misfit is poor at a finer level of detail. The forward model output suggests that the 3D geologic model with assumed, homogeneous rock unit densities contains 


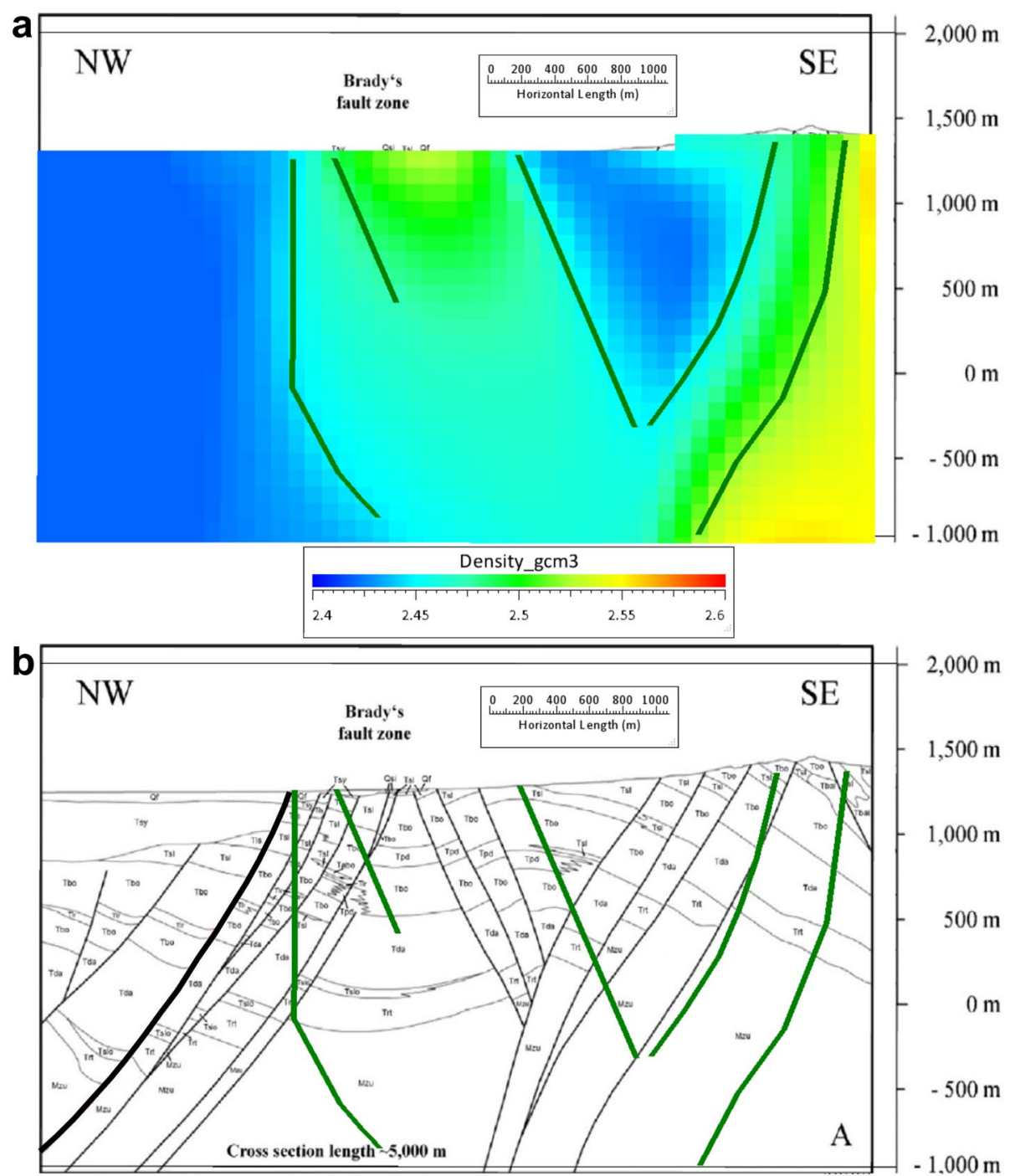

Fig. 6 a Density cross-section extracted from the unconstrained model in Fig. 5 that corresponds to a WNW-oriented geologic cross-section that crosses the Bradys fault zone (section A from Jolie et al. 2015). The density section is annotated with interpretation lines (green) which highlight boundaries between higher and lower density regions predicted by the unconstrained geophysical modeling. $\mathbf{b}$ Geologic cross-section A of Jolie et al. (2015) with the interpretation lines from the unconstrained density model overlain. The location and dip of the interpretation lines are consistent with the location and dip of faults in the southeast portion of the geologic cross-section, but they are not in the northwest portion of the cross-section near the Bradys fault zone. The location of the geologic cross-section is shown in map view in Fig. 4

density values that are too high in the central portion of the model (blue areas in Fig. 9c) and density values that are too low in the westernmost and easternmost quadrants (red areas in Fig. 9c). The overall RMS misfit of this density model is 2.18 mGal-substantially higher than the data uncertainty of $0.5 \mathrm{mGal}$.

In an attempt to reduce the misfit, we performed geophysical inversion modeling on the 3D geologic model again, kept the rock unit densities homogeneous, and allowed the inversion process to determine the optimal rock unit densities. After 55 iterations, the inversion modeling produced the density model shown in Fig. 10. Model densities 

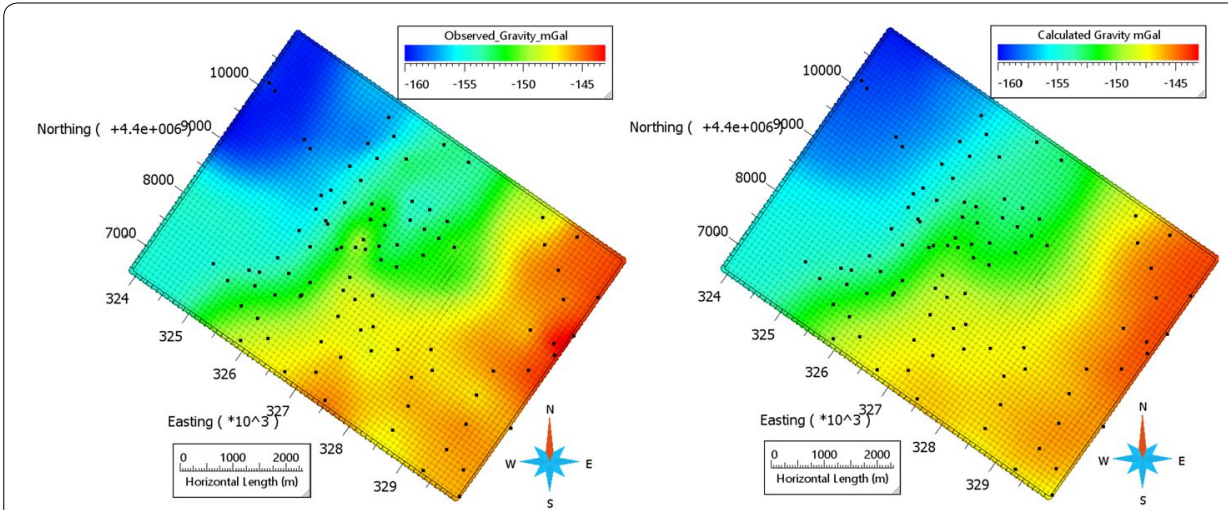

a Observed Data

b Calculated Data

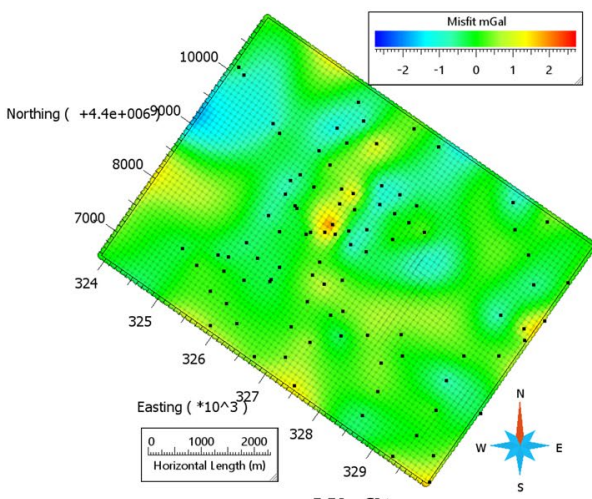

c Misfit

Fig. 7 Maps of the a observed gravity data, b gravity data calculated for the 3D unconstrained, heterogeneous density model, and $\mathbf{c}$ the RMS misfit between the two (i.e., misfit = observed - calculated). The majority of the misfit across the model area is near zero (green) and indicates good fit (RMS misfit $=0.46 \mathrm{mGal}$ ). Units on the color bars are mGal. Locations of gravity measurements are indicated by black dots

range from 2.04 to $2.74 \mathrm{~g} / \mathrm{cm}^{3}$ (Table 1 ). These model density values lie well within the range of geologically reasonable densities for the rock types in the Bradys area. The RMS misfit for this new density model has decreased by half to $1.04 \mathrm{mGal}$ (Fig. 11), but is still double the target misfit $(0.5 \mathrm{mGal})$. Approximately $60 \%$ of the model region has an acceptable misfit (green areas in Fig. 11c). Thus, we have generated a model for the Bradys area which honors the lithologic boundaries of the 3D geologic model, contains geologically reasonable rock densities, and comes close to quantitatively matching the observed gravity data.

\section{D geologically constrained density modeling with heterogeneous rock units}

The final step in the density modeling effort presented here is to allow for variable density within the individual rock units as a means to further reduce the misfit. Heterogeneous density is more geologically realistic and allows us to explore the density variations that are needed to obtain an acceptable misfit. Thus, geophysical inversion modeling was run a third time and density was allowed to vary within each individual rock unit. This inversion modeling effort ran for 7 iterations and returned a range in rock densities for nine of the rock units (Table 1). The density for Quaternary alluvium was left fixed at $1.9 \mathrm{~g} / \mathrm{cm}^{3}$. Figure 12 shows the variable density distribution in four of the volumetrically 


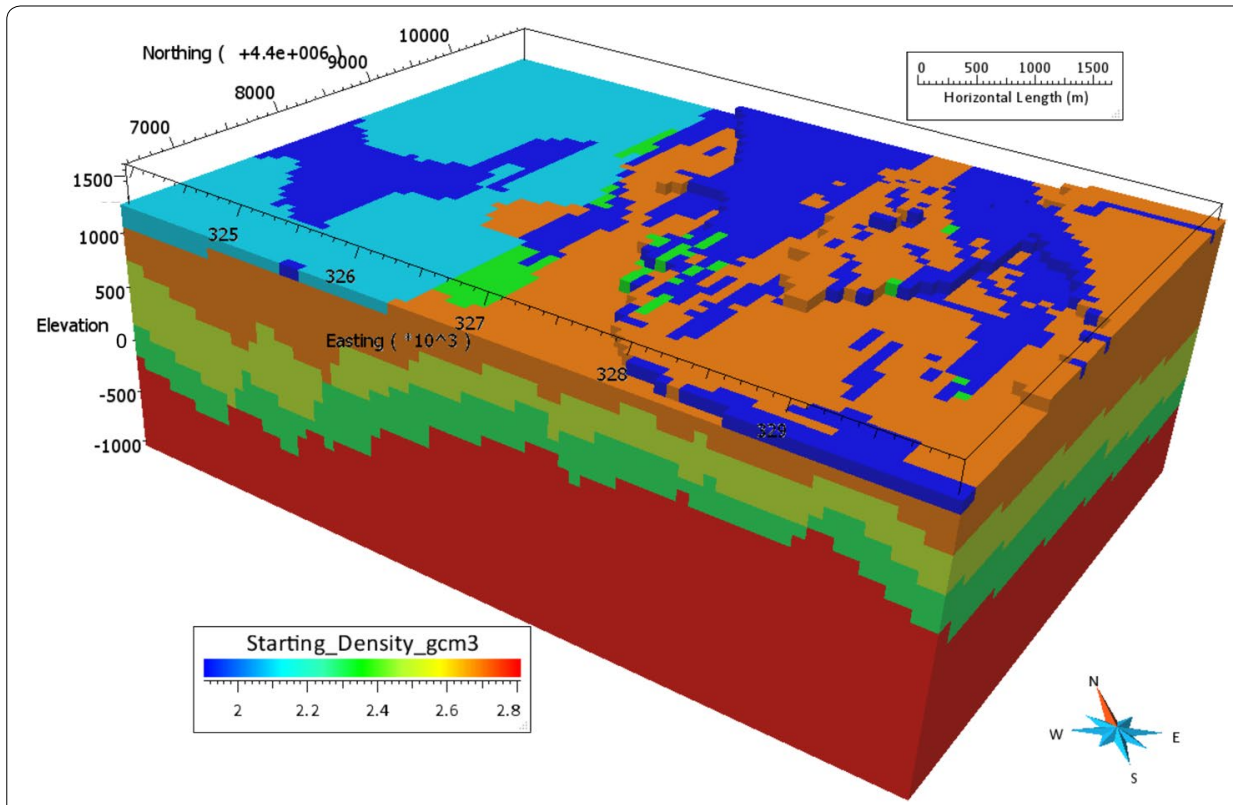

Fig. 8 Perspective view towards the north of the starting 3D density model for the Bradys geothermal area. Colors represent the assumed density values (shown in the color bar) for the different rock units. Specific density values assigned to each rock unit are shown in Table 1

dominant rock types in the Bradys 3D geologic model. The overall RMS misfit of this final model is good ( $0.55 \mathrm{mGal}$; Fig. 13) and is in agreement with the gravity data uncertainty $(0.5 \mathrm{mGal})$. This final model has succeeded at quantitatively integrating geological and geophysical data for the Bradys area within the limits of the data available. The model honors the lithologic boundaries of the existing 3D geologic model, contains geologically reasonable rock densities that vary within each rock unit, and is consistent with the observed gravity data.

Such a model is the starting point for further analysis and interpretation. Moving forward, the following questions need to be addressed: (1) Are the model densities consistent with rock density values measured in the Bradys area, and if not, how do the model density values need to be changed? and (2) How and where can the lithologic boundaries of the 3D geologic model be changed to address inaccurate model density values while at the same time maintain an acceptable level of misfit? (For example, can a dense rock unit be made thicker in one area of the model to address a density deficiency?)

\section{Discussion}

Rigorous, quantitative, and integrated 3D interpretation of geological and geophysical data is not yet the industry standard in geothermal exploration. Instead, simple visual overlay of 2D geological and geophysical maps and/or cross-sections is a more common practice. Such an approach results in little more than 'anomaly stacking' (Cumming 2009a). Unlike some unusually dense, strongly magnetic, or electrically conductive mineral deposits, the target fluids within geothermal systems are not known to generate a specific geophysical anomaly that is measureable at the surface. A more effective exploration method is the generation of integrated resource models which promote the 

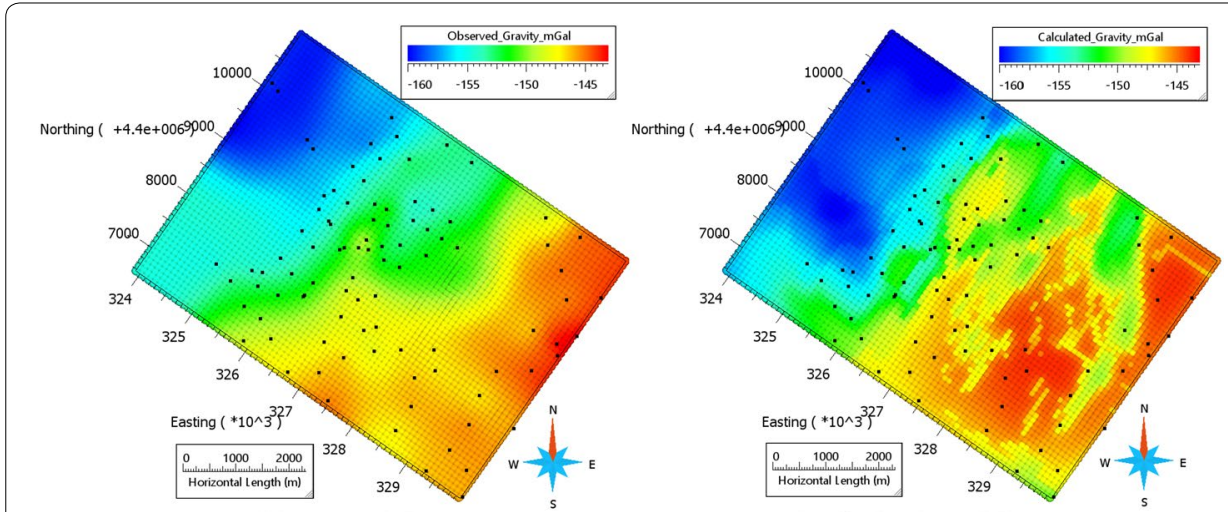

a Observed Data

b Calculated Data

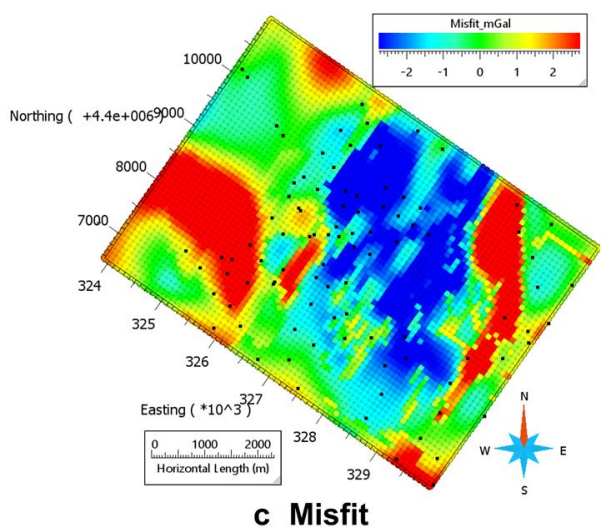

Fig. 9 Maps of the a observed gravity data, $\mathbf{b}$ gravity data calculated from the 3D geologic model with assumed, starting rock unit density values, and $\mathbf{c}$ the RMS misfit between the two (i.e., mis-

fit $=$ observed - calculated). The majority of the misfit across the model area is non-zero (i.e., not green) and indicates poor fit (RMS misfit $=2.18 \mathrm{mGal}$ ). Units on the color bars are $\mathrm{mGal}$. Locations of gravity measure-

ments are indicated by black dots

interpretation of geophysical data within the context of other geoscience information (Cumming 2009b).

A 3D geologic model that accurately characterizes the spatial distribution of rock type, alteration, and structure of a geothermal system is the fundamental starting point for testing ideas about the locations of potential reservoir rocks and permeable fluid pathways. Comprehensive and accurate 3D geologic models are difficult to construct because, typically, the available data are lacking (i.e., too few wells) or only surficial in scope (i.e., geologic maps). In areas that have insufficient data coverage, significant assumptions are required to build a 3D geologic model. Therefore, testing and then improving upon such a 3D geologic model prior to drilling is a critically important step for reducing drilling risk. Geophysical inversion modeling of gravity and/or magnetic data, constrained by the 3D geologic model, is a method that provides an objective and independent test of the 3D geologic model. Furthermore, if successful, it provides a validated 3D geologic model that can be used as input for a numerical reservoir model.

At the Bradys geothermal field, a 3D geologic model was generated using multiple geoscience datasets, which included: (1) geological and structural mapping, (2) interpreted seismic sections, and (3) geological well logs (Faulds et al. 2012 and unpublished mapping; Siler and Faulds 2013; Siler et al. 2016b). Uncertainties in the 3D geologic model 


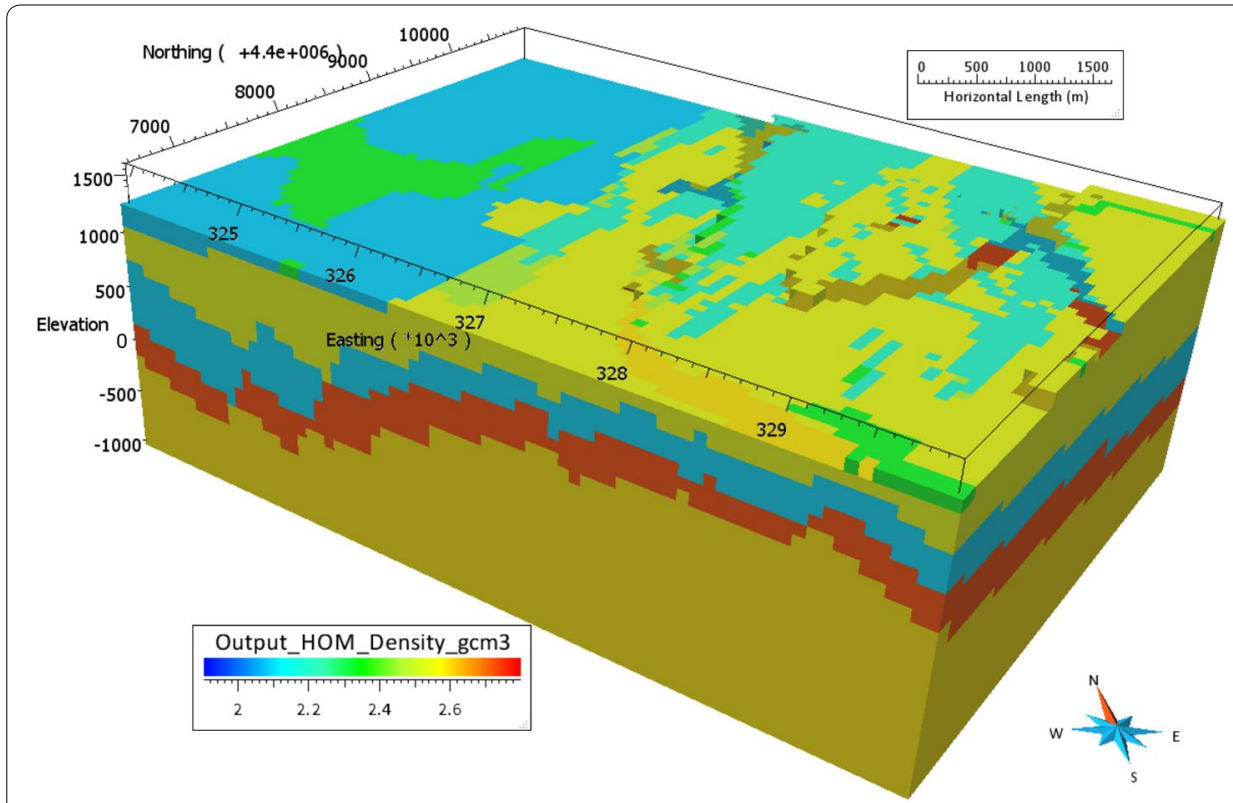

Fig. 10 Perspective view towards the north of a 3D density model for the Bradys geothermal area that is colored according to model density values derived from homogeneous unit geophysical inversion modeling. Specific density values for each rock unit are shown in Table 1

exist because: (A) most of the well control is restricted to the Bradys fault zone and (B) some of the surface geology and structure is obscured by alluvial cover. Faulds et al. (2010a) described specific challenges in geothermal exploitation at the Bradys geothermal field that arise due to uncertainty in the relationships between subsurface geology, structure, and fluid transmissivity. The goal of the work presented here is to test the Bradys 3D geologic model with the aim of improving it to ultimately enhance production at the field.

The geologically constrained geophysical inversion modeling effort presented here returned model density values that lie in the range $1.9-2.8 \mathrm{~g} / \mathrm{cm}^{3}$ (Table 1 ). This range of densities is geologically reasonable for the known rock types in the Bradys geothermal area. There is no need to call upon the presence of unusually high or low-density rock types at Bradys to explain the observed gravity data. If the density modeling did return extreme values, this would have cast serious doubts over the validity of the underlying geologic model. This did not occur in our geophysical modeling of the Bradys system and leads to the conclusion that the existing 3D geologic model is an acceptable starting model but in need of some refinement.

The model density values returned from both the homogeneous and heterogeneous, geologically constrained geophysical inversion modeling are the key guides for improving the 3D geologic model. In some cases, the assumed starting density matches quite well with the model density (e.g., rock unit Tsy; Table 1). Such agreement suggests that the shape and extent of the rock unit in question need not be changed. For other rock types, however, there is significant discrepancy between the initial and inverted density values. For example, rock unit Trt (Oligocene ash flow tuffs) has an assumed density of $2.3 \mathrm{~g} / \mathrm{cm}^{3}$ but the heterogeneous inversion modeling returned a density range of $2.68-2.80 \mathrm{~g} / \mathrm{cm}^{3}$. One argument to explain this discrepancy is that the Oligocene volcanic units are strongly welded ignimbrites giving rise to the high model density values. 

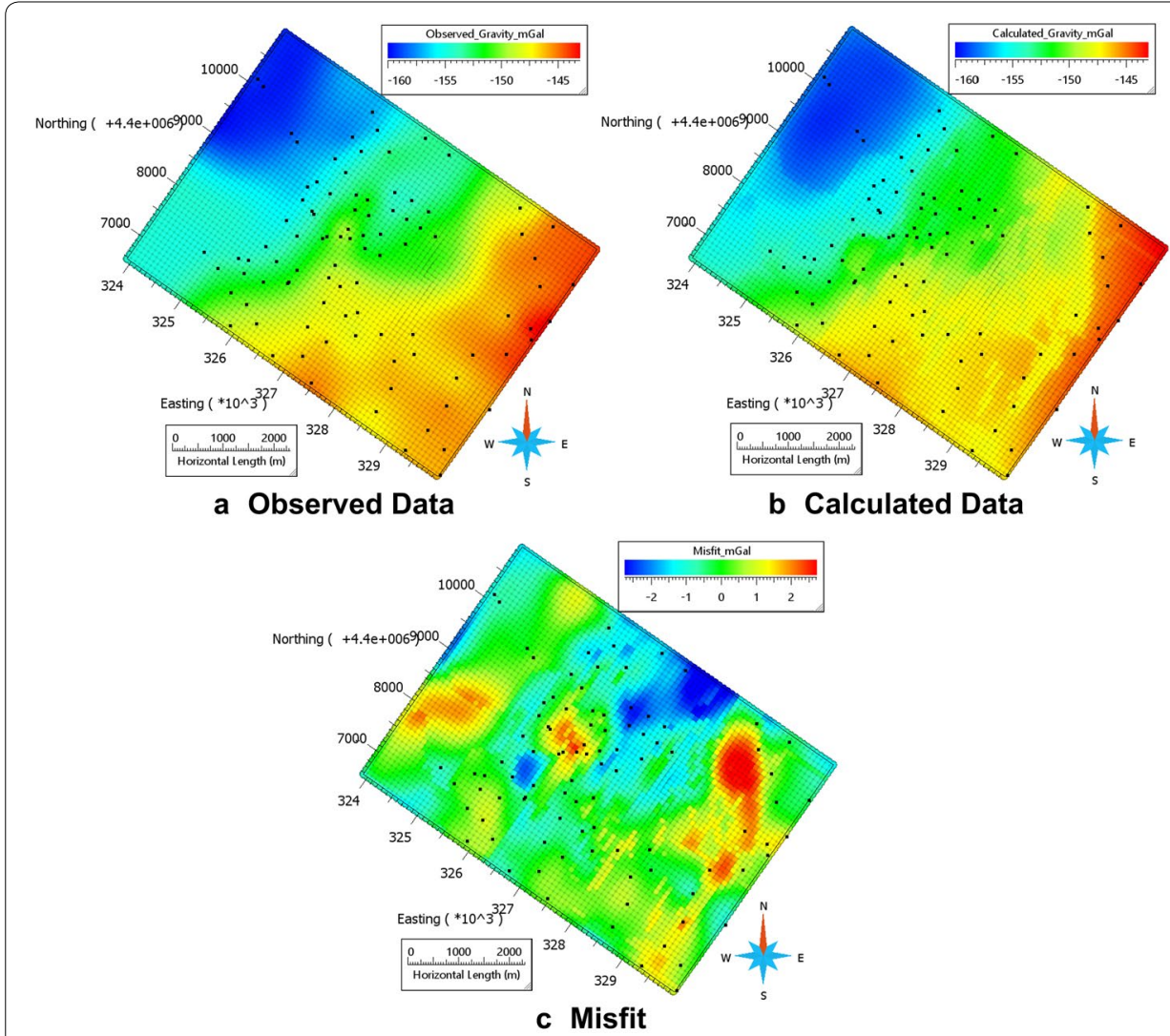

Fig. 11 Maps of the a observed gravity data, b gravity data calculated for the 3D geologically constrained homogeneous rock unit, density inversion model, and $\mathbf{c}$ the misfit between the two (i.e., misfit $=$ observed - calculated). The RMS misfit across the model area is characterized by large areas of zero (green) and non-zero (i.e., not green) misfit (RMS misfit $=1.04 \mathrm{mGal}$ ). The misfit is an improvement over that shown in Fig. 9. Units on the color bars are mGal. Locations of gravity measurements are indicated by black dots

However, the silicic composition of these rock units places this argument in serious doubt. Strongly welded silicic ignimbrites might have a density of $\sim 2.6 \mathrm{~g} / \mathrm{cm}^{3}$, but to achieve densities of $2.8 \mathrm{~g} / \mathrm{cm}^{3}$ more mafic compositions would likely be required (Dobrin and Savit 1988). Therefore, to rectify this apparent conflict in the density of rock unit Trt, a two-step approach is needed. First, measurements of the density of the Trt rock unit are essential to provide stronger evidence for the actual range of density of Trt. Second, the thickness and extent of the Trt unit can be changed in the 3D geologic model. Indeed, these Oligocene volcanic units are expected to have variable thickness laterally due to the valley-filling nature of ignimbrite emplacement (Sheridan 1979; Branney and Kokelaar 1992) and significant paleotopography in western Nevada in the Oligocene (Faulds et al. 2005; Henry et al. 2012). The higher model densities returned for Trt suggest that there may be too much low density Trt in the starting 3D geologic model. In other words, if the density of Trt is kept low in an updated model, the Trt layer would need to be made thinner (which would cause thickening of adjacent, higher density rock units) in order to achieve a match with the observed gravity data. In this manner, the results of the geophysical inversion modeling can be used to guide the changes that need to be made to the 3D geologic model. Importantly, the spatial variations in density 


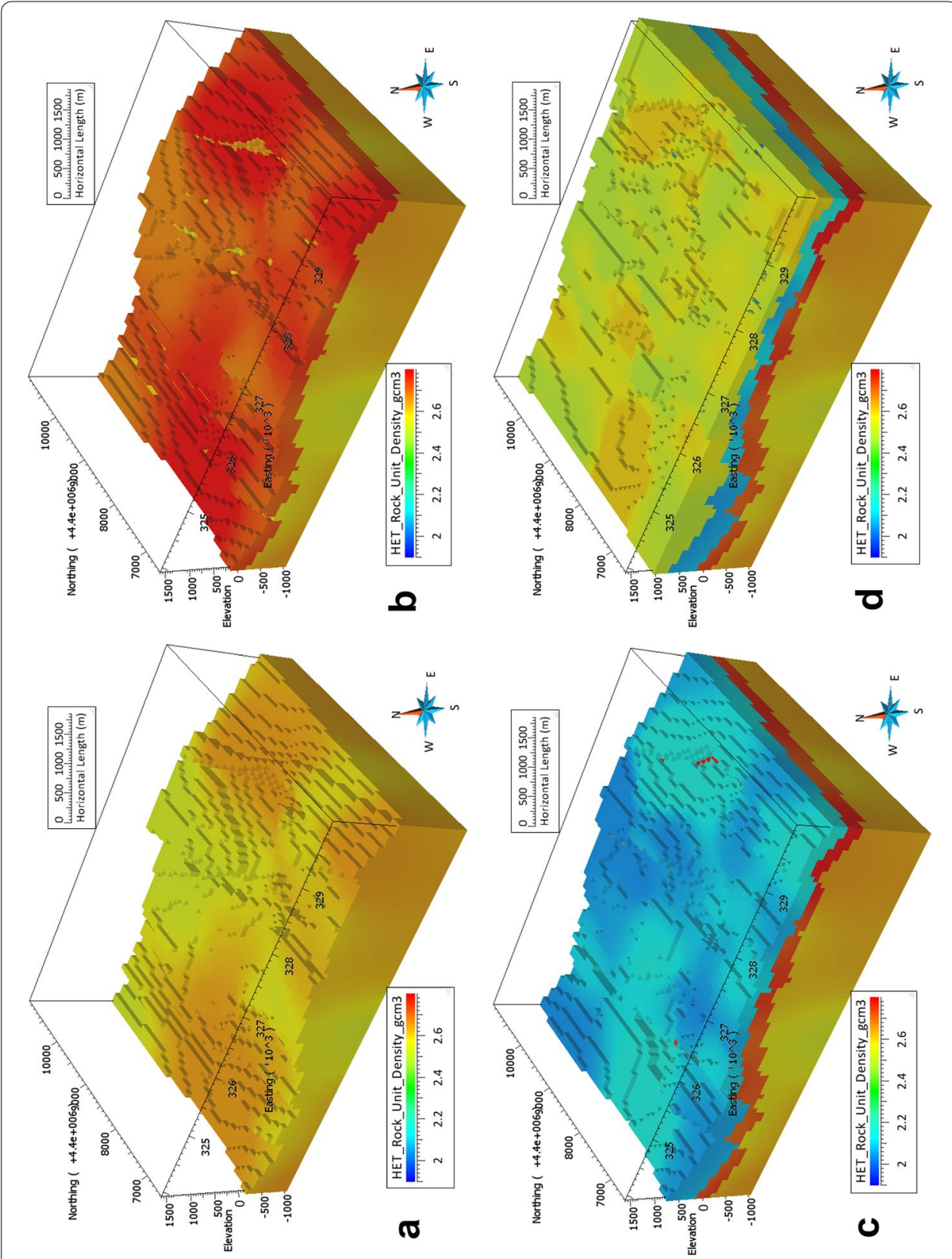

Fig. 12 Perspective view towards the north of a 3D density model for the Bradys geothermal area that is constrained by the 3D geological model but has variable density within individual rock units. Colors show density variation according to the color bar. Specific density ranges for each rock unit are shown in Table 1. Each panel shows the following rock units: a Mzu, b Mzu + Trt, c Mzu + Trt + Tda, and d $\mathrm{Mzu}+\mathrm{Trt}+\mathrm{Tda}+\mathrm{Tbo}$

returned in the heterogeneous rock unit inversion modeling serve as a key guide showing where in the 3D geologic model specific rock units should be thickened or thinned.

Although the results of the geophysical modeling effort at Bradys are encouraging, there are two important misgivings. First, gravity data coverage at Bradys is incomplete; there are significant holes in the study area with no data (Fig. 4). To address this problem, we interpolated across the data gaps using a standard 2D minimum curvature data 

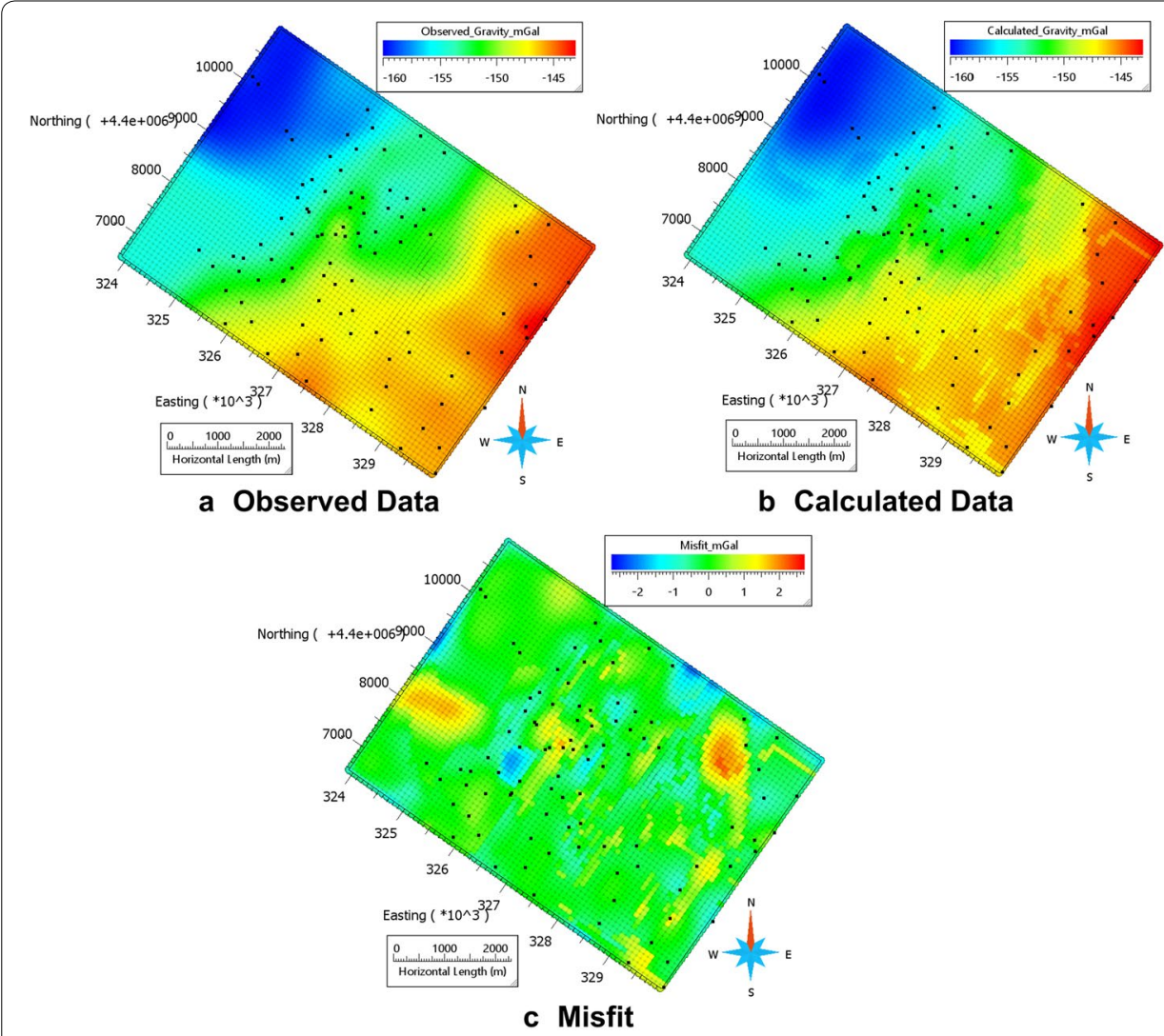

Fig. 13 Maps of the a observed gravity data, b gravity data calculated for the 3D geologically constrained heterogeneous rock unit, density inversion model, and $\mathbf{c}$ the RMS misfit between the two (i.e., misfit $=$ observed - calculated). The majority of the misfit across the model area is near zero (green) and indicates good fit (RMS misfit $=0.55 \mathrm{mGal}$ ). Units on the color bars are $\mathrm{mGal}$. Locations of gravity measurements are indicated by black dots

gridding technique to "generate" data where there were none. A much more rigorous approach, which would decrease uncertainty in the geophysical modeling, would be to obtain uniform coverage of gravity measurements across the Bradys geothermal field at a station spacing of 200-300 m. Second, the lack of measured density data from the study area means that a critical geological constraint is missing from the geophysical modeling. The use of assumed, starting density values imparts another level of uncertainty into the overall model results. Ideally, density data would be collected for all rock units in the Bradys area from surface samples and downhole. A sufficient number of density measurements should be performed to: (1) provide ample spatial coverage of each rock unit and (2) to facilitate the calculation of statistics to assess the distribution, range, and standard deviation of density in each rock unit.

Another limitation of the method presented in this paper is that the validity of a 3D geologic model can only be tested inasmuch as there exist detectable density contrasts between the rock units. Without density contrasts, the method is not helpful for geothermal exploration and other methods (e.g., magnetics, magnetotellurics) would need to be considered. Furthermore, in the best case scenario, the method discussed in this paper can only conclude that a $3 \mathrm{D}$ geologic model is consistent with the observed gravity data. The method cannot validate a geologic model in a strict sense. 


\section{Conclusions}

We present a methodology that both tests the validity of a 3D geologic model and provides direction as to how the 3D geologic model can be improved, especially in areas with no well control. The approach described here involves 3D geophysical inversion modeling of gravity data using the lithologic boundaries of an existing 3D geologic model as fixed constraints. The 3D geophysical inversion modeling was performed in three different ways to explore the possible distribution of density within the model: unconstrained, geologically constrained with homogeneous density rock units, and geologically constrained with heterogeneous density rock units. Actual measurements of rock density from the Bradys project area were not available for this study; however, representative values were used for starting densities. The existing 3D geologic model for the Bradys area, populated with these starting density values, is consistent with the observed gravity data on a broad scale. At a more detailed level, however, our analysis suggests that adjustments to the Bradys 3D geologic model need to be made in order to attain consistency between the observed gravity and the calculated gravity response. We explored the density model space using homogeneous rock unit and heterogeneous rock unit geophysical inversion modeling. An acceptable level of misfit (i.e., matching gravity data uncertainty) can be achieved using the existing 3D geologic model and allowing geologically reasonable, but variable density values in the individual rock units. Future improvements to the existing 3D geologic model would entail: (1) accurate characterization of the rock unit densities from measurements on rock core and surface samples collected from the Bradys geothermal area and (2) repositioning of rock unit boundaries to account for areas of density excess or deficiency while ensuring acceptable misfit. Updating the Bradys 3D geologic model is the subject of future work. Although the present study used gravity data to test the Bradys 3D geologic model, another independent test could be performed using magnetic data. A 3D geologic model which has been independently tested and then updated using the methods described in this paper will be more robust and have less uncertainty than those that have not been tested. Such an approach will facilitate a reduction in drilling risk, lead to more successful drilling programs, and serve as well-constrained geologic input to improve the accuracy of numerical reservoir models.

\section{Abbreviations}

IFC: International Finance Corporation; 2D: two-dimensional; 3D: three-dimensional; NBMG: Nevada Bureau of Mines and Geology; NGDS: National Geothermal Data System; RMS: root mean squared; Q: Quaternary sediments; Tsy: Miocene sediments; Tsl: Miocene lacustrine sediments; Tls: Miocene limestone; Tbo: Miocene basalt; Tpd: Miocene dacite and rhyodacite flows and domes; Tr: Miocene rhyolite lavas and tuffs; Tda: Miocene andesite and dacite lavas; Trt: Oligocene ash flow tuffs; Mzu: Mesozoic undivided meta-sedimentary and granitic rocks.

\section{Authors' contributions}

JF performed the geologic mapping and led the structural interpretation of the Bradys geothermal field with assistance from NH. NH produced geologic logs for all of the wells through logging of core and cuttings. DS performed the 3D geological modeling of the Bradys geothermal field with assistance from JF. JW performed the 3D geophysical modeling of gravity data from the Bradys geothermal field and wrote the manuscript. All authors edited the final manuscript. All authors read and approved the final manuscript.

\section{Author details}

${ }^{1}$ Mira Geoscience Ltd. 409 Granville Street, Suite 512B, Vancouver, BC V6C 1T2, Canada. ${ }^{2}$ Present Address: Innovate Geothermal Ltd., 104-445 West 2nd Avenue, Vancouver, BC V5Y 0E8, Canada. ${ }^{3}$ Energy Geosciences Division, Lawrence Berkeley National Lab, 1 Cyclotron Road, Berkeley, CA 94720, USA. ${ }^{4}$ Nevada Bureau of Mines and Geology, University of Nevada, Reno, MS 178, Reno, NV 89557, USA. 


\section{Acknowledgements}

Many thanks to Mira Geoscience for supporting this work. Additional thanks to Dr. Peter Fullagar for helpful discussions on this project and for reviewing a draft version of this paper. Part of this research was supported by grants from the U.S. Department of Energy (DE-FG36-02ID14311) and Ormat Nevada, Inc. We thank Ormat for significant, fruitful cooperation over the past $10+$ years.

\section{Competing interests}

The authors declare that they have no competing interests.

Received: 2 July 2016 Accepted: 30 September 2016

Published online: 11 October 2016

\section{References}

Benoit WR, Hiner JE, Forest RT. Discovery and geology of the desert peak geothermal field: a case history. Nevada Bureau of Mines and Geology. Bulletin. 1982;97:82. http://www.nbmg.unr.edu/dox/b97.pdf. Accessed 1 April 2016.

Blaikie TN, Ailleres L, Betts PG, Cas RAF. Interpreting subsurface volcanic structures using geologically-constrained 3-D gravity inversions: examples of maar-diatremes, Newer Volcanics Province, southeastern Australia. J Geophys Res Solid Earth. 2014;119:3857-78. doi:10.1002/2013JB010751.

Branney MJ, Kokelaar P. A reappraisal of ignimbrite emplacement: progressive aggradation and changes from particulate to non-particulate flow during emplacement of high-grade ignimbrite. Bull Volc. 1992;54(6):504-20.

Coolbaugh MF, Sladek C, Kratt C. Digital mapping of structurally controlled geothermal features with GPS units and pocket computers. Geotherm Res Counc Trans. 2004;28:321-5.

Cox C, Keller GR, Harder SH. A controlled-source seismic and gravity study of the high lava plains (HLP) of Eastern Oregon. Geochem Geophys Geosyst. 2013;14(12):5208-26.

Cumming W. Geothermal resource conceptual models using surface exploration data. In: Proceedings, thirty-fourth workshop on geothermal reservoir engineering. Stanford: Stanford University; 2009a.

Cumming W. A conceptual model approach to the geophysical exploration of permeable geothermal reservoirs that considers context and uncertainty. In: Society of exploration geophysicists technical program expanded abstracts. Houston: SEG International Exposition and Annual Meeting; 2009b.

Dobrin MB, Savit CH. Introduction to geophysical prospecting. 4th ed. Singapore: McGraw-Hill; 1988 .

Drakos PS (2007) Tertiary stratigraphy and structure of the southern Lake Range northwest Nevada: Assessment of kinematic links between strike-slip and normal faults in the northern Walker Lane. M.S. Thesis. Reno: University of Nevada, Reno.

Egger AE, Glen JMG, Ponce DA. The northwestern margin of the Basin and Range province part 2: structural setting of a developing basin from seismic and potential field data. Tectonophysics. 2010:488:150-61.

Faulds JE, Garside LJ (2003) Preliminary geologic map of the Desert Peak-Brady geothermal fields, Churchill County, Nevada. Nevada Bureau of Mines and Geology Open-File Report 03-27.

Faulds JE, Garside LJ, Oppliger G. Structural analysis of the Desert Peak-Brady geothermal fields, northwest Nevada: implications for understanding links between northeast-trending structures and geothermal reservoirs in the Humboldt structural zone. Geotherm Res Counc Trans. 2003;27:859-64.

Faulds JE, Henry CD, Hinz NH. Kinematics of the northern Walker Lane: an incipient transform fault along the PacificNorth American plate boundary. Geology. 2005;33(6):505-8.

Faulds JE, Coolbaugh MF, Vice GS, Edwards ML. Characterizing structural controls of geothermal fields in the northwestern Great Basin: a progress report. Geotherm Res Counc Trans. 2006;30:69-76.

Faulds JE, Coolbaugh MF, Benoit D, Oppliger G, Perkins M, Moeck I, Drakos P. Structural Controls of Geothermal Activity in the Northern Hot Springs Mountains, Western Nevada: the Tale of Three Geothermal Systems (Bradys, Desert Peak, and Desert Queen). Geotherm Res Counc Trans. 2010;34:675-84.

Faulds JE, Moeck I, Drakos PS, Zemach E. Structural assessment and 3D geologic modeling of the Brady's geothermal area, Churchill County (Nevada, USA): a preliminary report. In: Proceedings, thirty-fifth workshop on geothermal reservoir engineering, Stanford: Stanford University; 2010b.

Faulds JE, Ramelli AR, Garside LJ, Coolbaugh MF, Green HL. Preliminary geologic map of the Desert Peak Quadrangle. Churchill County, Nevada, Nevada Bureau of Mines and Geology, Open-File Report, 12-5; 2012.

Faulds JE, Hinz NH, Dering GM, Siler DL. The hybrid model—the most accommodating structural setting for geothermal power generation in the Great Basin, western USA. Geotherm Res Counc Trans. 2013;37:3-10.

Faulds JE, Hinz NH, et al. Characterizing structural controls of EGS-candidate and conventional geothermal reservoirs in the Great Basin: developing successful exploration strategies in extended terranes: Final report submitted to the Department of Energy; 2014

Fullagar PK, Pears GA. Towards geologically realistic inversion. In: Milkereit B, editor. Proceedings of exploration 07: fifth decennial international conference on mineral exploration, Toronto; 2007.

Fullagar PK, Pears GA, McMonnies B. Constrained inversion of geologic surfaces—pushing the boundaries. Lead Edge. 2008:1:98-105.

Heiskanen WA, Moritz H. Bull. Geodesique. 1967;86:491. doi:10.1007/BF02525647.

Henry CD, Hinz NH, Faulds JE, Colgan JP, John DA, Brooks ER, Cassel EJ, Garside LJ, Davis DA, Castor SB. Eocene-Early Miocene paleotopography of the Sierra Nevada-Great Basin-Nevadaplano based on widespread ash-flow tuffs and paleovalleys. Geosphere. 2012;8(1):1-27.

IFC. Best Practices Guide for Geothermal Exploration. Prepared by the International Geothermal Association in partnership with the International Finance Corporation of the World Bank Group. 2014. http://www.ifc.org/wps/ wcm/connect/topics_ext_content/ifc_external_corporate_site/ifc+sustainability/learning+and+adapting/ knowledge+products/publications/publications_handbook_geothermal-bp-2ed. Accessed 1 May 2016. 
Jolie E, Faulds JE, Moeck I (2012) The Development of a 3D structural-geologic model as part of the geothermal exploration strategy — a case study from the Bradys geothermal system, Nevada, USA. In: Proceedings, thirty-seventh workshop on geothermal reservoir engineering. Stanford: Stanford University.

Jolie E, Moeck I, Faulds JE. Quantitative structural-geological exploration of fault-controlled geothermal systemsa case study from the Basin-and-Range Province, Nevada (USA). Geothermics. 2015;54:54-67. doi:10.1016/j. geothermics.2014.10.003.

Khatiwada M, Keller GR. An integrated geophysical imaging of the upper-crustal features in the Harney Basin, southeast Oregon. Geosphere. 2015;11(1):185-200.

Lachenbruch AH, Sass JH. Models of an extending lithosphere and heat flow in the Basin and Range province. In: Smith RB, Eaton GP, editors. Cenozoic tectonics and regional geophysics of the Western Cordillera: geological society of america memoir. 1978;152: 209-50.

Li Y, Oldenburg DW. 3-D inversion of gravity data. Geophysics. 1998;63:109-19.

Moeck I, Schandelmeier $\mathrm{AH}$, Holl H. The stress regime in a Rotliegend reservoir of the Northeast German Basin. Int J Earth Sci. 2009;98:1643-54. doi:10.1007/s00531-008-0316-1.

Miller CA, Williams-Jones G. Internal structure and volcanic hazard potential of Mt Tongariro, New Zealand, from 3D gravity and magnetic models. J Volcanol Geotherm Res. 2016;319:12-28.

NGDS. National Geothermal Data System. 2015. http://geothermaldata.org/. Accessed 1 Nov 2015.

Oldenburg DW, Pratt DA (2007) Geophysical inversion for mineral exploration: a decade of progress in theory and practice. In: Milkereit B, editor. Proceedings of exploration 07: fifth decennial international conference on mineral exploration, Toronto; 2007.

Perrouty S, Lindsay MD, Jessell MW, Ailleres L, Martin R, Bourassa Y. 3D modeling of the Ashanti Belt, southwest Ghana: evidence for a litho-stratigraphic control on gold occurrences within the Birimian Sefwi Group. Ore Geol Rev. 2014;63:252-64.

Queen JH, Daley TM, Majer EL, Nihei KT, Siler DL, Faulds JE. Surface reflection seismic and vertical seismic profile at Brady's hot springs, NV, USA. In: Proceedings, forty-first workshop on geothermal reservoir engineering. Stanford: Stanford University; 2016

Saltus RW, Blakely RJ. Unique geologic insights from "non-unique" gravity and magnetic interpretation. GSA Today. 2011;21(12):4-11.

Sheridan MF. Emplacement of pyroclastic flows: a review. GSA Special Papers. 1979;180:125-36.

Siler DL, Mayhew B, Faulds JE. Three-dimensional geologic characterization of geothermal systems: Astor Pass, Nevada, USA. Geotherm Res Counc Trans. 2012;36:783-6.

Siler DL, Faulds JE. Three-Dimensional Geothermal Fairway Mapping: examples from the Western Great Basin, USA. Geotherm Res Counc Trans. 2013:37:327-32.

Siler DL, Faulds JE, Mayhew B, McNamara DD. Analysis of the favorability for geothermal fluid flow in 3D: astor Pass geothermal prospect, Great Basin, northwestern Nevada, USA. Geothermics. 2016;60:1-12. doi:10.1016/j. geothermics.2015.11.002.

Siler DL, Hinz NH, Faulds JE, Queen J. 3D analysis of geothermal fluid flow favorability; Bradys, Nevada, USA. In: Proceedings, forty-first workshop on geothermal reservoir engineering. Stanford: Stanford University; 2016b.

Stewart JH, Perkins ME. Stratigraphy, tephrochronology, and structure of part of the Miocene Truckee Formation in the Trinity Range-Hot Springs Mountains area, Churchill County, east-central Nevada, USGS Open-File Report 99-330; 1999.

Trevor MS, Wesnousky SG. The neotectonic character of the Granite Springs Valley and Bradys fault zones, western Basin and Range. Seismol Res Lett. 2001;72:256.

Watt JT, Glen JMG, John DA, Ponce DA. Three-dimensional geologic model of the northern Nevada rift and the Beowawe geothermal system, north-central Nevada. Geosphere. 2007;3(6):667-82.

Wesnousky SG, Barron AD, Briggs RW, Caskey J, Kumar S, Owen L. Paleoseismic transect across the northern Great Basin. J Geophys Res. 2005. doi:10.1029/2004JB003283.

\section{Submit your manuscript to a SpringerOpen ${ }^{\circ}$ journal and benefit from:}

- Convenient online submission

- Rigorous peer review

- Immediate publication on acceptance

- Open access: articles freely available online

- High visibility within the field

- Retaining the copyright to your article

Submit your next manuscript at $>$ springeropen.com 